\title{
THE REGULATION OF PRIVATE CONSERVATION LEGAL TOOLS IN CATALONIA: AN INSPIRING PRECEDENT FOR THE ROMAN LAW JURISDICTIONS
}

\author{
HeRnan Collado URIETA \\ Advocat
}

Recibido: 12 de septiembre de 2018 / Aceptado: 24 de enero de 2019

\begin{abstract}
During the first decades of the 21st century, Catalonia has successfully received Land Stewardship as a strategy for the conservation of nature. During this period, given the great opportunity that has been the parallel process of coding Catalan Civil Law, many efforts have been made to regulate Land Stewardship Agreements to the point of getting specific provisions in the Civil Code of Catalonia. In this article, I analyse the current civil regulation of the Land Stewardship Agreements in the Civil Code of Catalonia based on their essential elements and providing a critical view of the resulting legal framework. The objective is to disseminate the key learning and suggestions of the Catalan case for the professionals of the Land Stewardship around the world.
\end{abstract}

RESUM: Durant les primeres dècades del segle XXI, Catalunya ha acollit amb èxit la custòdia del territori com a estratègia per a la conservació de la natura. En aquest període, atesa la gran oportunitat que ha suposat el procés paral-lel de codificació del dret civil Català, s'han fet molts esforços per tal de regular els acords de custòdia fins al punt d'aconseguir introduir disposicions específiques en el Codi civil de Catalunya. En aquest article, analitzo la regulació civil actual dels acords de custòdia del territori al Codi civil de Catalunya partint dels seus elements essencials i aportant una visió crítica del marc jurídic resultant. L'objectiu és divulgar els aprenentatges i suggeriments clau del cas català per als professionals de la custòdia del territori de tot el món. 
RESUMEN: Durante las primeras décadas del siglo XXI, Cataluña ha acogido con éxito la custodia del territorio como estrategia para la conservación de la naturaleza. En este periodo, dada la gran oportunidad que ha supuesto el proceso paralelo de codificación del derecho civil Catalán, se han hecho muchos esfuerzos para regular los acuerdos de custodia hasta el punto de conseguir introducir disposiciones específicas en el Código civil de Cataluña. En este artículo, analizo la regulación civil actual de los acuerdos de custodia del territorio en el Código civil de Cataluña partiendo de sus elementos esenciales y aportando una visión crítica del marco jurídico resultante. El objetivo es divulgar los aprendizajes y sugerencias clave del caso catalán para los profesionales de la custodia del territorio de todo el mundo.

KEYWORDS: agreement - civil law - civil code - common law conservation - contract - easement — land — servitude — stewardship.

PARAULES CLAU: acord — dret civil — codi civil — common law — conservació — contracte - servitud - terra - servitud — custòdia.

PALABRAS CLAVE: acuerdo - ley civil - código civil - common law conservación - contrato - servidumbre - tierra — servidumbre - custodia.

SUMMARY: I. Introduction: the reception of Land Stewardship in Catalonia. II. Key elements of Land Stewardship agreements. 1. Duration and erga omnes effects. 2. Personal and appurtenant rights. 3. Reciprocity. III. The regulation of Land Stewardship agreements in the Civil Code of Catalonia. 1. Land Stewardship contract. 2. In rem right of partial use. 3. Appurtenant servitude. IV. Improvement of the current framework. V. Conclusions. VI. Bibliography.

\section{INTRODUCTION: THE RECEPTION OF LAND STEWARDSHIP IN CATALONIA}

Land Stewardship philosophy has been strongly transposed from AngloAmerican Common Law countries to European Roman law ones in the past two decades. This influence has been not only on non-profit conservation organisations but also on public institutions, who are interested in promoting Land Stewardship as a complementary strategy to public conservation action. 
The idea of Land Stewardship is to create legal binding of private landowners to conservation restrictions on the basis of private contracts that establish perpetual erga omnes obligations related to a piece of land for a public interest. However, the differences between the Common Law and the Roman law legal cultures make it far from easy to find functional equivalences between those contracts signed in the United States of America (conservation easements) and any of the private law instruments existing in most European countries.

Catalonia is an autonomous region of Spain situated at the North West corner of the Mediterranean Sea. Its 3.210.800 hectares (the size of Belgium) are very diverse, from the coast to the 3.143 meter highest peak, including prairies, Mediterranean and Atlantic forests, farmland, and middle and high mountain areas. The population of Catalonia is 7,523 million people (2016), more than 3,200 million of which live in the metropolitan area of Barcelona, its capital. Its self-government institutions include a Parliament which finds its origins in the XI century, and its own private law.

Catalonia has received Land Stewardship influence as many other European jurisdictions thanks to the contact of Catalan professionals with American Land Trusts during the nineties. Private conservation initiatives had taken place in Catalonia since the early eighties, but the constitution of Xarxa de Custòdia del Territori (Catalan Land Stewardship Network) in 2003 gave a common scope to all these initiatives and identified them under the term "custòdia del territori" (Land Stewardship in Catalan). The website of Xarxa de Custòdia del Territori gathers up most of what is been done after all these years, especially in its annual inventory that witnesses 765 agreements which affect 40.072,24 hectares (1.25\% of the Catalan territory), and 69 land stewardship organisations ${ }^{1}$.

Catalan Land Stewardship initiatives are based in legal agreements that give Land Stewardship organisations rights to grant conservation of certain natural, landscape or cultural values in private properties, through the right to monitor or even manage an alien property. These rights granted to the Land Stewardship organisation and the obligations held by the landowner in most cases go further than legal requirements granted by public regulations, but not always. In fact, in

\footnotetext{
${ }^{1}$ See CARNICERO, P., BLASCO, C. (2017).
} 
Catalonia as in the European context in general, urban planning and land regulations very often give a small room to conservation restrictions, being this a third obstacle to Land Stewardship transposition.

The Catalan Government has been interested in Land Stewardship from its reception in the early first decade of the XXI century, and has been working very closely with Land Stewardship organisations and especially with Xarxa de Custòdia del Territori. In Catalonia there is a great potential of properties with remarkable natural values that nowadays cannot find any viable management alternatives and fall in abandonment. In the case of forests, this implies a strong risk of fire due to climate conditions in the Mediterranean area. Nonetheless, Catalonia, as a relatively small territory with amazing diversity, gives no economies of scale in conservation action, and makes very difficult to establish models of Land Stewardship agreement.

Another feature of Catalonia is that, being a Mediterranean region, there is no much sense of philanthropy and social recognition for benefactors. Thus, legal and financial tools and incentives for conservation are needed to give response to this situation with the appropriate legal certainty even more than anywhere else, as nobody is going to mortgage his or her assets for nothing. One of the main directions of the coordinate work between the Catalan Government and Land Stewardship organisations is to achieve a Public Land Stewardship Agreements Register in order to determine the right to tax incentives. But a first and major step for this purpose is to determine the criteria by which one can sort those agreements that merit to be registered from those that do not, which is particularly difficult in Catalonia due to the mentioned diversity. Duration, content and legal form are the main items to be examined for this purposes ${ }^{2}$.

But probably the most important reason why the Catalan experience is interesting is the recent regulation of Land Stewardship contracts in the Civil Code of Catalonia. The private law regulation of Land Stewardship agreements has gone so far in Catalonia thanks to the great opportunity of Catalan private law codification. Catalan civil law has been actively developed and codified during the first two decades of the XXI century as a consequence of the consolidation of

\footnotetext{
2 See MASÓ, M. (coord.) (2015) and COLLADO, H., MASÓ, M. (2016).
} 
Catalan self-government after 1978 Spanish Constitution. In 2001, 22/2001 act ${ }^{3}$ regulated the in rem rights of partial use, which can be granted to a person with no relation between properties in the same way as personal servitudes. In 2006, Book V of the Civil Code of Catalonia ${ }^{4}$, related to property and in rem rights, was passed and rights of partial use were definitely included in its articles 563-1 to 4 . In 2008, article 40 of $1 / 2008$ act $^{5}$ regulated an agricultural land lease contract for "land stewardship and conservation purposes", and established that non-profit organisations had a "family farmer" status in any agricultural leases, which granted top guaranties for Land Stewardship organisations as lease holders. Finally, and more recently, in 2017, the Catalan Parliament passed Book VI of the Civil Code of Catalonia ${ }^{6}$, related to obligations and contracts, including the land stewardship contract, in article 623-34, as a modality of "contracts over alien object".

Although this nouvelle private law regulation is very weak and imprecise, it is a good starting point for a complete regulation. Many learning have still to be taken from countries like Argentina and Chile, and some other South American countries, as well as Canadian Québec, which have implemented conservation servitudes in Roman law jurisdictions. At the same time, many learning can be shared with the neighbour France, which makes its own parallel way, and with any European Roman law country willing to expand Land Stewardship legal tools at a national level.

\section{KEY ELEMENTS OF LAND STEWARDSHIP AGREEMENTS}

In this section I will start trying to highlight the aspects that I consider key in the

\footnotetext{
${ }^{3}$ Llei 22/2001, de 31 de desembre, de regulació dels drets de superfície, de servitud i d'adquisició voluntària $0 \quad$ preferent (abrogated) (https://dogc.gencat.cat/ca/pdogc_canals_interns/pdogc_resultats_fitxa/?action=fitxa\&document $\mathrm{Id}=283905)$.

${ }^{4}$ Llei 5/2006, de 10 de maig, del llibre cinquè del Codi civil de Catalunya, relatiu als drets reals (https://dogc.gencat.cat/ca/pdogc_canals_interns/pdogc_resultats_fitxa/?action=fitxa\&document Id $=422359$ ).

5 Llei 1/2008, de 20 de febrer, dels contractes de conreu (abrogated) (https://dogc.gencat.cat/ca/pdogc_canals_interns/pdogc_resultats_fitxa/?action=fitxa\&document $\mathrm{ld}=470965)$.

${ }^{6}$ Llei 3/2017, del 15 de febrer, del llibre sisè del Codi civil de Catalunya, relatiu a les obligacions

i els contractes

(https://dogc.gencat.cat/ca/pdogc_canals_interns/pdogc_resultats_fitxa/?action=fitxa\&document ld $=777422$ ).
} 
complex task of regulating conservation agreements into European legal systems.

Many existing private law instruments can be used for the aim of Land Stewardship (or conservation in private land). Leases, donations and purchase of freehold are examples by which Land Stewardship organisations can control private estates and manage them for conservation. In the same way, a free loan of land, and many in rem rights as for example usufruct can grant conservation if containing the appropriate clauses. This statement was very well defended in Catalonia by MIRAMBELL during the past decade ${ }^{7}$. However, given the gathered experience of more than fifteen years with Land Stewardship in Catalonia, we have understood that the regulation of specific legal tools for conservation is justified for two very essential reasons: on the one hand, the lack of suitability of contracts governed by civil law for the needs of the conservation of nature; on the other hand, the need for legal incentives to the signature of such agreements.

For the first reason, when we have a glance to the private law instruments potentially useful for conservation in private estates (e.g. transfer of use, lease, usufruct or ownership) we realize that very often those instruments put the global management of the farm in the hands of the Land Stewardship organisation. This consequence tends to be excessive for both parties, since the landowner does not want in all cases to completely abstain from the use and management of the property and the Land Stewardship organisation is neither always interested nor qualified to carry it out on its own. Thus, the formulas that do not transmit the global management of the farm but give a shared responsibility are those that in practice end up being the most successful.

From my point of view, therefore, there is a need to develop those instruments that extract only the faculties useful for conservation, leaving the rest of the enjoyment in the hands of the land owner, and these are undoubtedly the Land Stewardship contract and the conservation (personal) servitude. Both formulas are suitable to infinitely graduate the level of management the landowner yields, and can include, when appropriate, a complete transfer of the use. Parts can chose whether to formalise a contract (obligational) or servitude (in rem),

\footnotetext{
${ }^{7}$ See MIRAMBELL ABANCO, A. (2006).
} 
depending of the degree of legal certainty claimed by the Land Stewardship organisation and the commitment that the land owner is intended to give.

A second clear advantage of resorting to specific instruments for the conservation of nature is the incentive effect of the existence of the instrument itself. As provided in the preamble of the United States of America's Uniform Conservation Easements Act 1981, the regulation of conservation easement makes sense to provide legal advisers with a specific and flexible tool to cover all the rights and obligations that are of interest to the conservation of nature, and to judges a unified precedent ${ }^{8}$. The existence of specific legal tools is also understood as a general incentive when thinking of conservation in private land promotion in European countries ${ }^{9}$.

Nevertheless, whatever the legal option, any private contract aimed to grant conservation should fulfil certain requirements in some key elements, regardless of the essential elements of the contract regulated in art. 1.261 of the Spanish civil code (i.e. consent, object and cause) $)^{10}$. For the purposes of the present article, I will focus in three topics: duration and erga omnes effects; personal and appurtenant rights; and reciprocity.

\section{Duration and erga omnes effects}

Nature conservation initiatives may have very different features depending on the land they are meant to protect (e.g. forests, prairies or agricultural land), but in most of the cases the conservation of natural heritage and biodiversity is developed in the long term. In the countries where Land Stewardship contracts are best implanted, they are usually signed for perpetuity.

In contrast, in countries like Catalonia, where Land Stewardship is still at its beginnings, Land Stewardship organisations tend to sign agreements with more lax effects, for a short term and prioritizing trust and joint work with the land owner, often expecting the formalization of contracts with greater legal certainty and

\footnotetext{
8 "the easement alternative is favoured in the Act" because "lawyers and courts are most comfortable with easements and easement doctrine".

9 See DISSELHOFF, T. (2015).

10 Código civil español de 1889 (https://boe.es/buscar/doc.php?id=BOE-A-1889-4763).
} 
duration in the future ${ }^{11}$. Even when the conservation project involves the transfer of management, the preferred formula for formalizing it is the transfer of use, usually for short or precarious periods, in a way that avoids a compromise in the middle or long term ${ }^{12}$. Most Land Stewardship initiatives, thus, take the form of unnamed contracts or soft-law documents by which the Land Stewardship organisation and the landowner simply establish their common goals to protect natural, scenic or cultural values in the property. In these cases, enforcement in front the courts might not really be viable as concrete rights and obligations are not identifiable. What is more, we must bear in mind that a considerable part of Land Stewardship agreements is just aimed to implement land regulations, as the regulatory framework of agricultural and forest land in the Roman law countries, and specifically in Catalonia, is often very restrictive as I have already mentioned.

Nevertheless, a minimum duration is necessary for a greater guarantee as long as there is a use of public and social resources -i.e. public subsidiaries, private donations or volunteering- in private estates, so Land Stewardship organisations must ensure that these resources will remain in benefit of the public interest during the appropriate term. This is so understood, for example, in the granting of certain financing instruments, such as the LIFE European funds, which require the beneficiary organisation to be the holder of a right of ownership, in rem right or lease over the property in which it is going to perform conservation activities.

In the Roman law context, perpetuity is generally prohibited as a result of the liberal revolutions of the late eighteenth century in Europe, which wanted to avoid land grabbing by the nobility and the clergy (see Spanish desamortización) ${ }^{13}$. The modern Civil Code of Catalonia has set the maximum duration of the rights in 99 years ${ }^{14}$ to avoid unlawful situations inherited from years in which they had made sense (it is very well known the case of census, that still exist in many properties only because it is more expensive to cancel them than to satisfy them). So perpetuity is generally not a possibility in Roman law systems as far as I know.

Long-term duration is however better granted with erga omnes effectiveness, since inter partes agreements are always conditioned by the maintenance of the

\footnotetext{
11 See RODRIGO, J. (2015), section 2.1, page 21.

12 See CARNICERO, P., BLASCO, C. (2017).

13 See DURÁ ALEMAÑ, C.J. (2015).

14 Art. 563-2 Codi civil de Catalunya.
} 
property in the hands of the person granting the right. In rem rights are designed for the long term, and this makes them especially interesting for conservation.

Erga omnes effects will depend on the formal requirements accompanying the constituent title. At the outset, it is necessary for the parties to clearly set their will to establish the right with these erga omnes effects. But in many European countries like Catalonia this will affect the heirs of the grantor, but not to good faith acquirers unaware of the existence of the right. The second requirement, thus, is very often to formalise the title in a public deed and to register it in the Property Registry, which provides public registration.

Registration is not generally a request for in rem rights existence in the Spanish system, but could be in some other jurisdictions. For instance, the Law of the in rem environmental conservation right of Chile ${ }^{15}$ details the need to register the right in the term of 60 days from the date of the agreement.

Very often, Land Stewardship organisations seek alternative formulas to improve legal certainty also when using Land Stewardship contracts with inter partes effects. One of them is to include pre-emption rights in favour of the Land Stewardship organisation, which will allow to buy the property in case of transmission to a third party that is not interested in the agreement. However, landowners are rarely likely to burden their assets with such rights that compromise its future availability, albeit in a relatively low degree.

A second technique, usually more successful than the former, is to include in the contract the obligation of the landowner to notify the Land Stewardship organisation the intention to convey the estate to a third party and, in addition, to make sure that the acquirer will subrogate in the contract, considering otherwise that the contract has been breached. The landowner will be obliged, therefore, to condition the transfer to the subrogation of the purchaser to the Land Stewardship agreement, by means of condition of the purchase contract agreement. This technique somehow lays a bridge towards future landowners.

Long-term duration and erga omnes effects are the two essential legs of legal certainty in Land Stewardship agreements, and this should be worn in mind

15 Ley 20930 que establece el derecho real de conservación medioambiental (https://www.leychile.cl/Navegar?idNorma=1091906). 
wherever we want to regulate them. Nonetheless, in the Roman law tradition, the regulation of civil law instruments for the conservation of nature can combine two levels: inter partes (in personam) and erga omnes (in rem). Both of them make sense depending on the degree of confidence between parts, the commitment and capacity of the Land Stewardship organisation and financial needs of the agreement. And, nonetheless, it is difficult to understand one without the other, since they represent the same objective with different effects.

\section{Personal and appurtenant rights}

As I mentioned earlier, the main reference worldwide for Land Stewardship agreements are the American conservation easements. These private law instruments establish management restrictions over properties in benefit of conservation for perpetuity and with erga omnes effects. Conservation easements are private contracts in which a private landowner grants the management restrictions in benefit of the Land Stewardship organisation or any other non-profit organisation or Government body eligible to be a holder in a conservation easement according to the Uniform Conservation Easement's Act of 1981 of the United States of America ${ }^{16}$.

The ordinary functional equivalence of conservation easements in the Roman law systems are servitudes ${ }^{17}$, which can be established in benefit of a person (personal servitudes or servitudes in gross) or in benefit of a neighbour estate (appurtenant servitudes). In the case of personal servitudes, a concrete natural person or a legal entity stands as beneficiary of the servitude by the will expressed in the constituent title, regardless of any other circumstance. Instead, appurtenant servitudes benefit a neighbour estate, in a way that a person can take profit from the servitude to the extent that he or she is the owner of the land in benefit of which the servitude was established (dominant estate). All this because appurtenant servitudes are based on the idea that certain utilities are necessary for a certain estate (such as the way out to a main road or the access

\footnotetext{
16 See Section 1 (3) of Uniform Conservation Easement's Act 1981: "Third-party right of enforcement".

17 I'll use the French word "servitude" in English to differentiate European from American context, although "easement" would be perfectly correct as a translation of the Catalan "servitud" or Spanish "servidumbre".
} 
to water), and therefore appurtenant servitudes belong to the estate, whereas personal servitudes mainly consist of an economic profit (as for instance, timber or pasture).

American conservation easements are personal servitudes where the holder is a legal entity that, being a charity or a Government body, represents public interest in conservation. The profit granted by the easement with a private law technique will stay inactive thanks to the easement, as the landowner has no faculties to activate it and the Land Stewardship organisation aims to hold it just to keep it inactive, or to manage it for conservation. The personal servitude formula is, thus, the most suitable when we think of nature conservation.

However, in the context of the Roman law, servitudes are very rarely established for the benefit of a person or legal body. At this point, it is necessary to differentiate the Roman-French countries of those of Roman-Germanic influence. On the one hand, in the Roman-French, the concept of servitude (which must be appurtenant) has been separated from the forms that Roman law understood as personal servitudes, which are not other than the "usufruct", the "right of use" and other such as "using the labour force of alien cattle or slaves" (nowadays nonsense). On the other hand, in the Roman-Germanic, the concept of the "right of use over alien property" has been maintained, with several names ${ }^{18}$. This is why, in most modern civil codes, servitudes are solely considered to be of appurtenant nature as in servitudes the utility of the dominant property is always inherent ${ }^{19}$, despite in some of them equivalent formulas are regulated in benefit of a person.

For instance, in France, the debate on whether to regulate conservation servitudes or propter rem obligations, very well explained by MARTIN20, has finally opted for this second form ${ }^{21}$, as authors have definitely rejected the idea of a conservation personal servitude with no dominant estate.

Peculiarly, the Spanish Civil Code, which is entirely within the Roman-French tradition, recognizes the personal servitudes in its article 531 but they have never

\footnotetext{
${ }^{18}$ See NAVAS NAVARRO (2006).

19 See LUCAS ESTEVE (2014).

20 See MARTIN, G.L. (2008).

${ }^{21}$ See REBOUL-MAUPIN, N., GRIMONPREZ, B. (2016).
} 
been developed in any way ${ }^{22}$. Instead, Civil Code of Catalonia, of RomanoGermanic influence, has only very recently regulated the in rem rights of partial use, with identical features as personal servitudes, as we have already pointed and we will continue on later.

A third benchmark in which to keep an eye on is the Argentinian Civil Code, which always regulated personal servitudes. Article 2972 of the Civil Code of 1869, valid until 2015, advocated that "a personal servitude is the one that is constituted in the utility of some determined person, without dependence on the possession of a property, and that ends with the person." The current text of the Civil and Commercial Code of the Nation still further develops personal servitude ${ }^{23}$ in its article 2165, which states that "Personal servitude is the one constituted in favour of a determined person without inherent property of the dominant estate"24, and establishes, in more, than "in case of doubt, servitude is presumed personal." The duration of a personal servitude is presumed to be life, provided the constituent title does not specify a lower duration ${ }^{25}$. It can also be set up in favour of several holders at the same time ${ }^{26}$, simultaneously or successively, and the extinction for one of the holders does not extinguish it for the remaining ones. For legal entities, the interim duration is 50 years ${ }^{27}$.

But if it is clear that personal servitude, wherever they exist, could apparently be preferred for conservation purposes, it is not always like this. For instance, in Argentina appurtenant servitudes are preferred to personal as the former can grant perpetuity whereas the latter do not ${ }^{28}$.

Moreover, in South America, we can mainly identify experiences of the use of appurtenant servitudes for conservation purposes, as in most studied cases it is the only chance as civil law only admits the appurtenant servitudes ${ }^{29}$. To carry out this formula, the Land Stewardship organisation must acquire neighbouring

\footnotetext{
22 As NAVAS NAVARRO (2006) comments, there are very few references, doctrinal comments or precedents regarding personal servitudes in Spain.

${ }^{23}$ See CARAMELO, G. et al. (2015), page 270.

${ }^{24}$ All translations of Spanish and Catalan legal provisions into English are made by my own.

${ }^{25}$ Art. 2165 Código Civil y Comercial de la Nación.

${ }^{26}$ Art. 2167 Código Civil y Comercial de la Nación.

${ }^{27}$ Art. 2182 Código Civil y Comercial de la Nación.

${ }^{28}$ Personal coment of Luís Castelli (Fundación Naturaleza para el Futuro, Argentina).

${ }^{29}$ See civil codes of Chile (arts. 820 et seq.), Colombia (arts. 937 et seq.), Costa Rica (arts. 370 et seq.) i Perú (arts. 1.035 et seq.).
} 
land, or the landowner must segregate part of the land to be preserved and transfer it to the Land Stewardship organisation by purchase or donation. With this conveyance, the Land Stewardship organisation obtains the dominant land in favour of which to establish the servitude, or even in some cases to constitute mutual servitudes. This practice has not, however, ceased to be experimental: even in Costa Rica, which has been a pioneer in its implementation since the first decade of this century, the use of conservation servitude has been residual in comparison to private reserve or other forms of privately protected areas arranged with the public administrations.

To conclude, personal servitudes are the most suitable for nature conservation in private land, for the reasons that I have pointed out, although the use of appurtenant servitudes can be useful wherever personal are not admitted or in order to grant perpetuity. In addition to this, appurtenant servitudes may be interesting to expand conservation from estates previously owned by Land Stewardship organisations, as it happens in Québec ${ }^{30}$. Also private owners may be interested to restrict certain faculties in some neighbour land in order to improve environmental quality in their own with strictly private interest and regardless of any tax exemption, but nevertheless in favour of conservation of natural values. All this considering the existence of an environmental utility and focused in its future recognition by law as we will see latter on.

\section{Reciprocity}

From my point of view, the matter of whether Land Stewardship agreements are reciprocal or non-reciprocal (onerous or gratuitous) transactions is never too controversial given the very important consequences of one or the other conception. In this section, I expect to warn about the importance of this crossroads.

In the United States of America, conservation easements are assumed gratuitous by tax law, as far as they are signed under Uniform Conservation Easement's Act, whenever the contrary is not said. In a conservation easement a land owner gives the land trust faculties that can represent a very significant profit (such as

\footnotetext{
${ }^{30}$ Personal coment of Cristian Duchesne (Nature Conservancy of Canada).
} 
housing or mining) for perpetuity. Whenever the land owner does not receive a payment for this profit that will remain restricted for life, this transaction is very cleverly considered a donation, what is to say a gratuitous transaction. The value of the donation is equivalent to the lost profits which are appraised by a qualified assessor, giving the result of this appraisal both the value of the donation and the new value of the land for any tax purposes.

However, this is not universally so conceived. First because in some cases a Land Stewardship organisation can buy the faculties needed for conservation, or even lease or buy the whole estate; and secondly because Land Stewardship action may be understood as a payment in kind.

Article 7.3 of Chilean Ley 29930, which is a modern regulation of Land Stewardship, opens all possibilities when establishing that parts will declare whether the conservation right is reciprocal or non-reciprocal and, in its case, which is the price or other consideration agreed. In other words, it's up to parts.

In the case of Catalonia, instead, Land Stewardship agreements have been understood as onerous (reciprocal) legal transactions from the very beginning, in the sense that the land owner is the beneficiary of the ecological services of the land, which will be improved with the agreement, and even of a general improvement of the land due to this better natural quality ${ }^{31}$. This is an opposite sense in which American easements are understood, as long as American easements mean a burden to the land as a consequence of which its value decreases to the extent that certain profits are no longer possible.

In Catalonia, the responsibility of the holder for guaranteeing the fulfilment of the purpose of the agreement, collaborating in the planning, conservation action and monitoring the natural resources of the estate is understood as a payment in kind. This is a good argument for "selling" Land Stewardship to land owners ("you give some faculties; you get a better quality land"). However, this conception of Land Stewardship agreements closes the door to donation tax incentives: as long as the owner receives something in return, there is no impoverishment; then tax deductions will be only applicable in the case of donation of the whole property right.

${ }^{31}$ See O.G. VÁZQUEZ ASENJO (2011). 
The conception of Land Stewardship agreements as reciprocal transactions is very clear in the text of the Civil Code of Catalonia, with the expression "in exchange", as we will see immediately, so it is there to remain for better and for worse. As I understand it, this is a challenge for private law conservation in Catalonia, where substantial tax incentives, whenever they are finally foreseen, may be for very restricted situations (i.e. donation of land).

\section{THE REGULATION OF LAND STEWARDSHIP AGREEMENTS IN THE CIVIL CODE OF CATALONIA}

In the following sections, I offer a close look to the complete regulation of Land Stewardship in the Civil Code of Catalonia, including both contracts with in personam effects and in rem rights, and suggesting the possibility of regulating appurtenant conservation servitudes.

I will start with the Land Stewardship contract, recently introduced in Book VI of the Civil Code of Catalonia, related to obligations and contracts, passed by $3 / 2017$ act. This land Stewardship contract can have either in personam or in rem effects, as we will see.

Next, I will explain the regulation of in rem rights of partial use in Book $V$ of the Civil Code of Catalonia, related to property rights, passed by 5/2006 act. These in rem rights are the equivalent to personal servitudes and expressly include its potential use for conservation.

Finally, I will have a glance to appurtenant servitudes also regulated in Book V, and its potential use for conservation.

\section{Land Stewardship contract}

Article 623-34 of the Civil Code of Catalonia regulates Land Stewardship contract as it follows:

"1. In the Land Stewardship contract, which is temporary and whose purpose is land property, the grantor partially or totally allows the use or management of the land to the holder, which must be a legal entity having Land Stewardship among its purposes, in exchange for carrying out 
advisory, outreach, planning or management and improvement activities, in order to conserve biodiversity, natural and cultural heritage and landscape or to make sustainable management of its natural resources.

2. The rights constituted in favour of the holder may be in personam or in rem, whenever they satisfy, in this case, the requirements stated by law.

3. The legal framework of the Land Stewardship contract, as to the determination of the obligations of the parties and their failure to comply, the duration or guarantees, is the one freely determined by the contractual parties."

Some aspects of this regulation merit a close look that I will make in the next paragraphs. First of all, the idea of transfer of use implicit in this regulation; secondly, the lack of regulation of the content of the contract; thirdly, the "double nature" of the contract, as it can become an in rem right; fourthly, the reciprocal nature; and, finally, the obstacles envisaged when thinking about its implementation with erga omnes effects.

\section{a) Definition}

The Land Stewardship contract is defined in article 623-34.1 as a contract by which "the grantor partially or totally allows the use or management of the land to the holder". The idea of land use transfer (totally or partially) goes somehow beyond what has been understood as the content of Land Stewardship agreements in Catalonia to the date, which in many cases only imply the mandate to advice or monitor in exchange for limiting the management faculties in favour of the conservation of the existing natural values. Certainly, it is interesting to include the transfer of land use as one of the possibilities of the Land Stewardship contract, but Land Stewardship is not only where there is direct management, so the scope of the contract is clearly insufficient.

\section{b) Content of the contract}

Article 623-34.3 does not add much more information about the legal regime of the contract, and it is limited to saying that it will be freely established by the parties, without making any reference to an additional rule in case of doubt. This is a great weakness of the regulation, bearing in mind the inspiring precedent of Chilean 20.930 act that establish the in rem right of environmental conservation, 
whose article 6 states the minimum stipulations necessary to understand that we are in front of "burdens that have the purpose of preserving the environmental heritage":

- «The restriction or prohibition of assigning the property to real estate, commercial, tourist, industrial or agricultural use, forestry or other purposes», being this a maximum degree of restriction.

- The obligation to directly or indirectly take over the "maintenance, cleaning, decontamination, repair, protection, administration or rational use" of the farm.

- The obligation to execute or monitor a management plan for the sustainable management of natural resources.

It is still more interesting, however, the negative definition in article 6, according to which the contracts that establish burdens on the property that (1) are not specific, (2) only consist of complying with current regulations or (3) do not conform to the provisions of the Law, will not be eligible as in rem rights of environmental conservation.

In this sense, it is clear enough that a content of rights and obligations is necessary, and there is no doubt about the additionality requirement, that is to say, that the compromise with force of law that is derived from the contract exceeds the obligations that are required by the public regulations applicable to the land in which the estate is located.

In the Catalan regulation, instead, there is a lack of a basic content of rights and obligations, or even an interim duration in case it is not foreseen by parts, and thus any mere memorandum of understanding could be considered a Land Stewardship contract under article 623-34 of the Civil Code of Catalonia. This connects with the issue of Land Stewardship agreements' quality, and the criteria by which they can be eligible for tax incentives, being this regulation absolutely useless for this purposes.

c) The reciprocal nature

Regarding to the reciprocity of the Catalan Land Stewardship contract, it is essential to point out the expression "in exchange", which is also present in article 563-1 regulating in rem rights of partial use, as we will see. The consequences 
of this understanding have been already commented, but I would like to insist at this stage that it will strongly condition the design of tax incentives whenever Catalan Government want to regulate them, for the reasons already pointed.

d) The double nature in personam and in rem

Perhaps the most innovative and interesting contribution of this provision to the Catalan Land Stewardship contract is in section 2 of article 623-34 when it states that "The rights constituted in favour of the holder may be in personam or in rem whenever they satisfy, in this case, the requirements stated by law".

The requirements that article 623-34-2 refers to are no other than simply the will of the grantor to give the rights with erga omnes effects, since its establishments in a public deed and the registration of in the Land Registry are only requirements for publicity and public registration according to the Catalan and the Spanish civil codes and to the Spanish Mortgage Law32.

The possibility of establishing all the agreed in a Land Stewardship contract with erga omnes effects opens clear possibilities and almost gives an instrument equivalent to the Chilean in rem right of environmental conservation. However, there is a lack of an interim regime for this in rem right constituted by the will of parties, as there is no reference to these in rem rights in Book $V$ of the Civil Code of Catalonia, on property rights, that are thus only regulated in Book $\mathrm{VI}$, on obligations and contracts. Certainly, article 563-1 to 563-4 of the Civil Code of Catalonia regulates the in rem rights of partial use, the object of which can be, literally "to manage and obtain forestry in exchange for restoration and conservation of natural and landscape resources or conserving the fauna and ecosystem", but there is no specific remission to this article in article 623-34 CcC.

Given the French experience ${ }^{33}$, one of the possibilities is that the Catalan legislator is in fact thinking of a propter rem obligation although this is not expressed in article 623-34 CcC. In Catalonia there is a solid doctrine for the existence of such obligations, but they are basically understood as positive

32 Art. 149.1 .8 of 1978 Spanish Constitution (https://boe.es/buscar/doc.php?id=BOE-A-197831229) gives exclusive competency to the State for the legislation on registers and public instruments. Spanish Mortgage Law is in Decreto de 8 de febrero de 1946, por el que se aprueba la nueva redacción oficial de la Ley Hipotecaria (https://boe.es/buscar/doc.php?id=BOE-A-19462453).

33 See REBOUL-MAUPIN, N., GRIMONPREZ, B. (2016). 
obligations that run with the property of a certain estate (as for instance, the obligation to maintain the fence of a neighbouring farm ${ }^{34}$ ), and this is not always the case in conservation in rem rights, which will normally consist in not to do obligations.

In addition to this, we should question the use of the partial use in rem rights for Land Stewardship purposes regulation once in rem rights can be established by a Land Stewardship contract.

\section{In rem right of partial use}

The in rem right of partial use is described in article 563-1 to 563-4 of the Civil Code of Catalonia as it follows:

"The rights of partial use established with in rem nature in favour of a person on an alien property regardless of any relationship between estates, including to manage and to obtain forestry in exchange for restoration and conservation of natural and landscape resources, or to conserve its wildlife and ecosystem, to graze livestock and herds, to prune trees and cut mates, (...) and similar, are governed by the rules of this section and, in what is not opposed to them, by their constitution title, by the custom and by the rules that regulate the right of usufruct, whenever compatible."

The regulation of the in rem rights of partial use opened a solid door, in 2006, to the establishment of restrictions of use on a farm for the benefit of third parties in a very similar way to conservation easements.

\section{a) Definition}

The in rem right of partial use is defined in article 563-1 as this established "in favour of a person on an alien's property regardless of any relationship between estates". Its legal regime is freely determined by the parties, just like in the Land Stewardship contract, but in this case articles 563-2 to 563-4 regulate an interim and a maximum duration in 30 and 99 years, and make reference to the regulations of usufruct for further interim framework when compatible, among

\footnotetext{
${ }^{34}$ See LUCAS ESTEVE, A. (2015).
} 
other aspects related to its in rem nature such as redemption.

b) Content

The regulation of the content of this in rem right of partial use, however, does not go beyond the listing of a series of examples, which give us a rough orientation of what we are talking about. The first example seems to refer to Land Stewardship: "to manage and to obtain forestry in exchange for restoration and conservation of natural and landscape resources, or to conserve its wildlife and the ecosystem".

However, the legal relationships established by these agreements have such particular features that we cannot be satisfied with this description. First of all, because, as already said, the diversity of nature conservation initiatives in Catalonia (and presumably elsewhere) is so great that it is very difficult to reach a common core (for instance, forestry is just one of the many profit existing in a farm where natural values are to be preserved: it could be agriculture or livestock, or it could not exist any profit); and secondly, because Land Stewardship is a non-profit interest with very little in common with those legal transactions where the particular profit is the aim.

c) The reciprocal nature

Again, it is clear is that the legislator is thinking in a reciprocal transaction: the Land Stewardship organisation obtains the right to manage and obtain forest use and the land owner must tolerate this action in exchange for the benefits of the conservation action on the land. We can clearly say that the in rem right of partial use, when used for conservation purposes, is defined as a payment in kind in exchange for the owner's restrictions.

\section{d) Current implementation}

Up to the date, in Catalonia, there are eleven in rem rights of partial use signed in private estates for the conservation of nature where the grantor is a private owner and the holder is a Land Stewardship organisation ${ }^{35}$. The constitution of these in rem rights is made in accordance with the following assumptions:

- The content of the in rem right of partial use is a non-possessory interest

\footnotetext{
${ }^{35}$ See CARNICERO, P., BLASCO, C. (2017).
} 
of the Land Stewardship organisation that entails certain obligations to do and not to do both for property and for itself ${ }^{36}$.

- Obligations not to do include environmental restrictions that limit the management of the farm, whoever is the holder.

- Obligations to do can include monitoring, advising or conservation action.

- An economic payment for the landowner can be established, in some cases (although it is not essential).

- In some cases, an additional obligation for the landowner is established to contribute to the conservation objective, either in cash or in kind (vehicles, machinery, etc.).

- Usually, the established rights are for a period of between 20 and 30 years.

- All in rem rights of partial use used for conservation are registered in the Land Registry entitled as "in rem rights of partial use".

\section{Appurtenant servitude}

Conservation appurtenant servitudes are not regulated in Catalonia, and there is no precedent of using them for conservation purposes neither in Catalonia nor in Spain. However, in South America and Canada they are currently successfully used, and this is why I dedicate a specific section of the present article to this kind of servitudes.

\section{a) Definition}

The right of servitude is regulated in articles $566-1$ to $566-13$ of the Civil Code of Catalonia. This regulation defines servitudes as in rem rights established on a estate (called "servant") for the benefit of another (called "dominant") consisting in the granting of a "certain use" 37 to the dominant or the reduction of the faculties of the owner of the servant.

b) Content

Regarding to its content, the Civil code of Catalonia merely states that it must be

${ }^{36}$ See BOISÁN CAÑAMERO, I. J. (2015).

37 Utility. 
a utility for the dominant estate, from which is not separable, and that it must be exercised in the most suitable way for the utility of the dominant and, at the same time, the less uncomfortable and harmful for the servant estate. There is no limitation regarding the contiguity or distance between estates, so that will be determined according to the nature of the utility.

Civil Code of Catalonia only regulates appurtenant servitudes of "lights and views", access to general services, right of way and water rights, although there is no express establishment of a numerus clausus in the acceptable servitudes. Moreover, article 566-1.1 seems to suggest a numerus apertus in the following expression: «The holders of servitude can benefit the servant estate in the way determined by its constituent title or by this Code».

\section{c) Constitution and payment}

Servitudes can be established voluntarily or as required by law (art. 566-2.1 CcC). Article 566-10 CcC clearly establishes the obligation to give payment to the landowner deprived from the faculties to establish a servitude required by law, but nothing is said about voluntary servitudes. Therefore, we understand that voluntary servitudes can be established both for free and in exchange of a payment or reward at the parties' will, being it also possible in kind.

\section{d) Neighbouring of servant and dominant land}

Regarding neighbouring, in order to establish appurtenant servitude, a Land Stewardship organisation must own a neighbour estate or even, according to article 566-3 CcC, be owner of both estates (dominant and servant). There is no essential need for the two estates to be contiguous, as long as the utility is satisfied.

\section{e) The environmental utility}

The existence of environmental utilities is a more delicate matter and also the core of conservation servitudes whenever they are used. Conservation servitudes are posed on the basis of the existence of such a thing as an environmental utility whose evidence relies on biological or landscape parameters and always in application of the precautionary principle. Legally speaking, environmental utility is a much controverted idea, which has never been recognized by courts so far, but only by an arbitration court case in 
Argentina $^{38}$. At the same time, the utility is absolutely tight to the duration of appurtenant servitude, which will last as long as the environmental utility exists (presumably in perpetuity). This condition implies a work in progress sense of the duration in conservation servitudes: the technical conditions that allow assuring the existence of the environmental utility are reviewed throughout the time, so that we ensure the fulfilment of servitude only while it technically makes sense ${ }^{39}$. The defense of environmental utility arises from the concept of environmental service and its importance, and it is the relation between the two concepts that defines the essence of appurtenant conservation servitudes.

\section{IMPROVEMENT OF THE CURRENT FRAMEWORK}

Given what is shown in the previous sections, it is clear that the Catalan civil regulation of Land Stewardship needs a holistic look to make a sensible revision. The steps I point out bellow should be taken into account for these purposes ${ }^{40}$.

First of all, the development of the very incipient regulation of the Land Stewardship contract following the example of Chilean Law:

1) Description of the Land Stewardship contract and its purposes;

2) Regulation of the minimum content of rights and obligations and excluded contracts;

3) Reference to the economic payment or reward as a non-essential element of the contract;

4) Regulation of the interim duration and reference to the maximum duration of the rights of the Civil Code of Catalonia (99 years);

5) Reference to the regulation of the in rem right of partial use as an interim regime in the case of establishing itself with erga omnes effects.

Secondly, once the Land Stewardship contract is fully developed, with its

\footnotetext{
38 See the case Lagunas de Epu Lauquen, in Argentina (Tribunal de Arbitrage General y Mediación de la Facultad de Derecho y Ciencias Sociales de la Universidad de Buenos Aires, 20th september 2002).

39 See ERNEAUX, P.Y. (2005), ap. 12.

40 In my 2016 research I develop the articles that should be introduced in the Civil Code of Catalonia, but I understand that this is not interesting for the scope of the present article. Should the reader be interested in this, see COLLADO, H. (2016).
} 
possibility to be established with erga omnes effects, in rem rights of partial use provisions may be useless for conservation purposes other than being an interim regulation. Thus, a specific section for Land Stewardship in rem rights should better be introduced in Book $\mathrm{V}$ of the Civil Code of Catalonia and current reference to conservation of article 563-1.1 should be removed.

Thirdly, the regulation of an environmental appurtenant servitude could be a very innovative proposal in Catalonia, since the use of this instrument has never been previously proposed. However, knowledge of its use in the context of South America has been inspiring to the point of seeing it possible as an instrument for the conservation of nature in Catalonia in perpetuity. The conservation servitude regulation may include the following:

1) The legal establishment of the concept of environmental utility.

2) The relationship between estates.

3) The content of rights and obligations.

4) The constitution and payment.

5) The duration.

\section{CONCLUSIONS}

As a conclusion of this article, I want to point out the following main ideas that I understand that should be born in mind when thinking of a private law regulation of Land Stewardship agreements in European countries.

First of all, the specific regulation of Land Stewardship agreements is necessary in order to offer a perfect match between the aims of parties and the civil law forms with the appropriate legal certainty, and also to create a legal incentive to make things happen.

Secondly, both in personam and in rem effects are interesting for conservation purposes, as there are infinite agreements to be reached for conservation in private land and not all conservation projects need long term in rem bindings. A joint regulation -as it is in Catalonia- makes sense as certain content can be set for different effects depending on the will and capacity of parts. 
Thirdly, personal and appurtenant rights can be useful for conservation. If it is true that personal servitudes seem to be the most suitable for conservation, thanks to their functional equivalence with conservation easements, appurtenant rights are also useful when a previous estate is owned for conservation purposes. In addition to this, appurtenant rights provide perpetuity wherever law does not admit it for personal servitudes as long as environmental utility is recognized.

Fourthly, according to the Catalan experience, the reciprocal or non-reciprocal nature of Land Stewardship agreements is an important crossroads to decide at the very beginning, as it has important tax consequences and thus is determinant for the implementation of Land Stewardship in a country.

And, finally, the regulation of Land Stewardship agreements must be complete and include matters such as content, formalities needed to grant the rights of the holder, interim duration, eligibility of agreements and public registration in order to effectively build a legal framework giving legal certainty to the Land Stewardship contract's parties.

\section{ACKNOWLEDGEMENTS}

In 2016, I made a research on private law tools for the conservation of nature in Catalonia, thanks to a grant of the Centre d'Estudis Jurídics i Formació Especialitzada of the Department of Justice of the Catalan Government. The main objective of that research was to arrive at a proposal for a coherent regulation of civil law instruments for the conservation of nature in Catalonia, taking into account the existing provisions and the bill of the future Book VI of the Catalan civil code, on obligations and contracts (now already passed). The present article has been aimed to extract and translate into English the essential outputs of the Catalan experience for worldwide practitioners of Land Stewardship, especially in Roman law jurisdictions.

I want to express my gratitude to the following people who helped me in the research that gave rise to the present article, due to their dedication of time to show me their realities, to send me valuable bibliographical references and to give feedback to partial contents: Julie Babin (Fédération des Conservatoires d'Espaces Naturels, France), Javier Beltrán (The Nature Conservacy Argentina), 
Luís Castelli (Fundación Naturaleza para el Futuro, Argentina), Tilmann Disselhoff (European Land Conservation Network), Christian Duchesne (Nature Conservancy of Canada), Jaume Hidalgo Colomé (Acció Natura, Projecte Sèlvans, Catalonia), Laura Johnson (International Land Conservation Network, USA), Guillem Mas Cornet (Paisatges Vius, Catalonia), Montse Masó Aguado (environmental consultant, Catalonia), Lisa McLaughlin (Nature Conservacy of Canada), Florencia Morales (Coordinadora de la Red Argentina de Reservas Naturales Privadas), Roberto Peralta (Chile), Veronique Rioufol (Tèrre de Liens, France), Marteen Roels (Tèrre en Vue, Belgium), Antonio Ruiz (Foro de Redes y Entidades de Custodia del Territorio, Spain), Carles Sunyé Salvà (Acció Natura, Projecte Sèlvans, Catalonia) and Eerika Tapio (ELY, Finland).

The ideas I expose in this paper were also presented in the International Workshop in Legal Tools for Private Land Conservation, organized by the European Land Conservation Network, which took place in Rovaniemi (Finland) on 14th and 15th June 2018, where I could attend thanks to Fundación Biodiversidad (Ministerio para la Transición Ecológica. Gobierno de España).

\section{BIBLIOGRAPHY}

ALVARADO RAMÍREZ, A., ESPINOZA VILLALOBOS, J.P. Servidumbre ecológica en costa rica "nueva modalidad para la conservación privada". Tesis para optar por el grado de licenciado en derecho. Facultad de Derecho, Universidad de Costa Rica. Noviembre de 2013. Available at: http://iij.ucr.ac.cr/wp-content/uploads/bsk-pdf-manager/2017/06/ServidumbreEcol\%C3\%B3gica-en-Costa-Rica-\%E2\%80\%9CNueva-modalidad-para-laconservaci\%C3\%B3n-privada\%E2\%80\%9D.pdf.

BARREIRA, A. (coord.), et al. (2010). Estudio jurídico sobre la custodia del territorio. Madrid: Plataforma de Custodia del Territorio de la Fundación Biodiversidad. Available at: http://custodiaterritorio.es/sites/default/files/recursos/estudio_juridico_custodiaterritorio_2010. pdf.

BARRIT, E. Conceptualising Stewardship in Environmental Law. Journal of Environmental Law, Oxford University Press. 2014.

BOISÁN CAÑAMERO, I. J. (2015) Custodia del territorio. Configuración jurídica. 
Titulación e inscribilidad. Ponència a les XVIIlenes Jornades de Dret Català a Tossa. Universitat de Girona. 2014. Available at: http://mbnotarios.com/uploads/web_works/mandbnotariosconferenciaijbccustodi a-del-territorio.pdf.

BYERS, E., MARCHETTI PONTE, K. (2005). The conservation easement handbook. Washington, D.C.: Land Trust Alliance; San Francisco (LA): Trust for Public Land.

CARAMElO, G., HeRRERA, M., PICASSO, S. (2015). Código Civil y Comercial de la Nación Comentado. Tomo V. 1a ed. Ciudad Autónoma de Buenos Aires: Infojus.

CARNICERO, P., BLASCO, C. (2017). VII Inventari d'acords i entitats de custòdia del territori a Catalunya. Informes de la Xarxa de Custòdia del Territori, núm. 27. Vic (Barcelona): Xarxa de Custòdia del Territori. Available at: http://www.xct.cat/ca/cdt/inventari.html.

CASTELLI, L. (2001). Conservación de la naturaleza en tierras privadas. Argentina: Fundación Ambiente y Recursos Naturales. Available at: http://www.conservacionprivadapy.org/documentos_pdf_mundial/Conservacion \%20privada\%20en\%20Argentina.pdf.

COLLADO, H. (2015). Opcions per a la custòdia del territori en finques privades. Guia dels acords de custòdia del territori. Vic (Barcelona): Xarxa de Custòdia del territori. Available at: http://www.xct.cat/mm/file/2015/2015_Opcions_x_custodia_territori_Guia_Acord s.pdf.

COLLADO, H., CORTINA, A. (2012). Qualitat i seguretat jurídica dels acords de custòdia del territori. Vic (Barcelona): Xarxa de Custòdia del Territori. Quaderns per a entitats de custòdia del territori, núm. 05.

COLLADO, H., MASÓ, M. (2016). Informe sobre criterios y sistemas de acred itación de la custodia del territorio en el estado español. Vic (Barcelona): Xarxa de Custodia del Territori. Available at: http://www.xct.cat/mm/file/cdr/Doc_ocasional_26_sistemas_acreditacion_y_regi stro_CdT.pdf.

COLLADO, H. Els instruments de dret civil per a la conservació de la natura a Catalunya. Una proposta per a la seva regulació al Codi civil de Catalunya. Centre d'Estudis i Formació Especialitzada. Departament de Justícia de la 
Generalitat de Catalunya. Programa d'ajuts a la investigació especialitzada 2016. Available at: http://cejfe.gencat.cat/ca/recerca/cataleg/crono/2017/dret-civilnatura-cat/.

DISSELHOFF, T. (2015). Alternative Ways to Support Private Land Conservation. Report to the European Commission, Ref. No: E.3PO/07.020300/2015/ENV. Available

at: http://ec.europa.eu/environment/life/publications/lifepublications/generalpublicati ons/documents/support_land_conservation.pdf.

ERNEUX, P.Y. La servitude environnementale en droit belge. Unpublished. 2015.

FERNÁNDEZ, E. Protection de l'environnement naturel et proprieté priveé. Environmental Law in Delveloping Countries. Selected Issues Vol. II. BURHENNE-GUILMIN, F. (coord.). UICN Environmental Policy and Law Paper, num. 43, Vol II. 2004.

LINDT, B. (1991). The conservation easement stewardship guide. Washington, D.C.: Land Trust Alliance; Concord, N.H.: Trust for New Hampshire Lands with assistance from the National Trust for Historic Preservation.

LINDT, B. (2001). Working Forest Conservation Easements. Washington, DC: Land Trust Alliance.

LUCAS ESTEVE, A. (2015). Dret Civil Català Volum IV. Tom 1. Drets reals. Possessió, propietat i situacions de comunitat. Barcelona: J. M. Bosch editor. MARTIN, G. L. Pour l'introduction en droit français d'une servitude conventionelle ou d'une obligation propter rem de protection de l'environnement. Revue juridique de l'environnement. № Extra 1, 2008. Available at: https://www.persee.fr/doc/rjenv_0397-0299_2008_hos_33_1_4710.

MIRAMBELL ABANCO, A. La custòdia del territori en finques privades. Contratos de custodia del territorio. Col-legi de Notaris de Catalunya. Revista LA NOTARIA, L Not 35-36. Barcelona: Ed. Marcial Pons, novembre-desembre 2006. MIRAMBELL ABANCO, A. La regulació dels drets reals al Llibre cinquè del Codi civil de Catalunya. La codificació dels drets reals a Catalunya. Àrea de Dret Civil Universitat de Girona (coord.). Materials de les Catorzenes Jornades de Dret Català a Tossa, 21 i 22 de setembre de 2006. Available at: http://civil.udg.edu/tossa/2006/textos/pon/1/aba.htm.

MASÓ, M. (coord.). (2015). Guia de bones pràctiques a entitats de custòdia del 
territori. Bones pràctiques en gestió de les entitats i les iniciatives de custòdia del territori. Vic (Barcelona): Xarxa de Custòdia del Territori. Available at: http://www.xct.cat/mm/file/cdr/151130_Guia_bones_practiques_DEF.pdf.

NAVAS NAVARRO, SUSANA. (2007). El derecho real de aprovechamiento parcial. Cuadernos de Derecho Registral. Madrid: Fundación Registral.

NAVAS NAVARRO, S. Recursos naturales, valores culturales y contratos de custodia del territorio. Contratos de custodia del territorio. Col-legi de Notaris de Catalunya. Revista LA NOTARIA, L Not 35-36. Barcelona: Ed. Marcial Pons, novembre-desembre 2006.

REBOUL-MAUPIN, N., GRIMONPREZ, B., L'obligation réelle environnementale: chronique d'une naissance annoncée. Recueil Dalloz, Dalloz, 2016, p. 2074. Available at: https://hal.archives-ouvertes.fr/hal-01550578.

RODRIGO, J. (2015). Anàlisi dels recursos i necessitats de les entitats de custòdia membres de la XCT. Vic (Barcelona): Xarxa de Custòdia del Territori. Available at: http://www.xct.cat/mm/file/2016/Informe_visites_def.pdf.

SWIFT, B., BASS, S., et al. Legal tools and incentives for private lands conservation in Latin America: building models for success. Washington, D.C.: Environmental Law Institute. (2003). Available at: https://cmsdata.iucn.org/downloads/spn__legal_tools_and_incentives_for_priv ate_lands_conservation.pdf.

VÁZQUEZ ASENJO, O.G. Reflexiones sobre los acuerdos de custodia del territorio. Seminari de seguretat jurídica i fiscalitat de la custòdia del territori. Xarxa de Custòdia del Territori. 2011. Available at: http://www.xct.cat/mm/file/iniciatives/juridic/111115_seminari_juridic.rar. VÁZQUEZ ASENJO, O.G. Reflexiones sobre la custodia del territorio. Ponència a les XVIIlenes Jornades de Dret Català a Tossa. Universitat de Girona. 2014. Available at: http://civil.udg.edu/tossa/2014/textos/pon/5/VAZQUEZ.pdf. 